\title{
OM RUTH
}

\author{
BOYE WANGENSTEEN
}

Tiden går, og i mai i år var det 35 år siden Ruth kom feiende som et friskt vær inn i norsk leksikografi da hun ble tilsatt som vitenskapelig assistent på Avdeling for bokmål ved det som da het Norsk leksikografisk institutt. Instituttet holdt til på Chateau Neuf i Slemdalsveien inntil det ble slått sammen med Nordisk institutt i 1990 og flyttet til Blindern i 1992.

Før Ruth gikk i gang med studiene, hadde hun jobbet i det private næringsliv, og innimellom studiene underviste hun i forskjellige skoleslag. Det ble tidlig klart at Ruth hadde faglige ambisjoner. I 1988 ble hun doktorgradsstipendiat og det ble forskerutdanning i språkvitenskap. I årene 1991-1997 fungerte hun som amanuensis og fra 1997 som førsteamanuensis ved instituttet, som skiftet navn $i$ takt med nye omorganiseringer. Etter hvert hadde hun ferdig en stor doktoravhandling med tittelen Rimelig ut fra sakens art. Om tolkning av ubestemte adjektiv $i$ regelgivende språk, som hun disputerte på i 1998. Hun ble dr.philos. og professor i nordisk språkvitenskap samme år. I 2013 ble hun valgt som prorektor ved Universitetet i Oslo.

Ruth har vært veileder for mange masteroppgaver, og hun var den første som arrangerte metodekurs for masterstudentene ved ILN. Hun har vært opponent ved flere doktordisputaser i inn- og utland, og hun har vært gjesteforeleser bl.a. i Litauen, USA, Russland og Etiopia. Hun har også vært mye benyttet som bedømmer av søknader for flere nordiske institusjoner, f.eks. Svenska Akademien og Velux-fonden i Danmark.

Ruth har alltid lagt stor vekt på nordisk og internasjonalt samarbeid. Det var hun som tok initiativet til og fikk gjennomført den første store nordiske konferansen i leksikografi, som ble arrangert i Oslo allerede i 1991. Det var på denne konferansen Nordisk forening for leksikografi (NFL) ble stiftet, og foreningen har siden arrangert nordiske konferanser i leksikografi fast hvert andre år. Hva dette samarbeidet som NFL initierte, har betydd for faget leksikografi i Norden, kan knapt overvurderes.

Ruth var med i styret i NFL i mange år og var leder fra 2003 til 2005. Hun startet og redigerte internbladet NFL-nytt i årene 1992-2002. Etter at hun ga seg, har bladet avgått en stille død. Hun var en av de seks nordiske redaktørene av 
Nordisk leksikografisk ordbok, med hovedansvar for de semantiske termene innenfor leksikografifaget. Boka kom ut i 1997. I en årrekke var hun norsk redaksjonsmedlem i LexicoNordica, tidsskriftet som Nordisk forening for leksikografi har gitt ut siden 1994, og i årene 2010-2011 var hun den ene av de to hovedredaktørene. I årene 2006-2012 var hun styremedlem i den europeiske foreningen for leksikografi, EURALEX.

Det er blitt mange artikler fra Ruths hånd opp gjennom årene, i LexicoNordica, i rapportene fra de nordiske leksikografikonferansene og i andre språkvitenskapelige tidsskrifter. Hun redigerte også den første konferanserapporten fra konferansen 1991 og kalte den Nordiske studier i leksikografi. Serien er nå kommet til nr. 14.

Ruth har lagt ned mye arbeid på å utvikle faget leksikografi, bl.a. ved at hun i mange år, og så lenge tilbudet eksisterte, hadde ansvaret for undervisningen i leksikografi ved det instituttet faget til enhver tid hørte til. Sammen med Lars Vikør har hun skrevet Ord og ordbøker på Høyskoleforlaget i 2008, en omfattende innføring i leksikologi og leksikografi, og den første på norsk.

Ruth har vært hovedarkitekten bak det store prosjektet Leksikografisk bokmålskorpus (LBK), som ble ferdig i 2013. Korpuset består av over 100 millioner ord, og det er et fantastisk hjelpemiddel både for ordboksarbeid og annen språkforskning.

I 2018 kom Norsk banneordbok på Humanistisk forlag, et nybrottsarbeid som gir en omfattende dokumentasjon og analyse av banneord og kraftuttrykk fra hele landet.

Feltet språkrøkt bør også nevnes. Det begynte med mange kurs i praktisk norsk rundt omkring alt i studietiden, og den første boka Ruth ga ut, Norsk til kontorbruk på Universitetsforlaget, kom for over 30 år siden. Den kommer stadig i reviderte opplag, den siste i 2017 med tittelen Skriv godt og riktig på jobben. Her kan også nevnes Lingua Bokmålsordliste med skriveregler på Kunnskapsforlaget i 2008.

I årene 2000-2012 var Ruth språkkonsulent i NRK, der hun fulgte etter størrelser som Finn-Erik Vinje og Dag Gundersen. Hun har også vært benyttet som ekspertvitne i mange rettssaker om ord og varemerker.

Ruth har aldri vært redd for å tone flagg og ta en frisk diskusjon. Hun har alltid hatt mot til å stå fram og målbære det hun mener er rett og aldri gått på akkord med sine prinsipp. (Selv om hun er leksikograf, er det mye som tyder på at hun ikke kjenner ordet og begrepet opportunisme.) Det hadde vært underlig om slike egenskaper ikke hadde ført til konflikter av og til, særlig når de er representert av en kvinne. Det har nok Ruth opplevd fra tid til annen, men med sitt mot og sin fightervilje har hun alltid stått fjellstøtt på sitt. 
Ruth har stor arbeidskapasitet og en imponerende energi, og hun har vært engasjert på flere samfunnsområder også utenom det rent faglige. Hun var leder i Bymålslaget i ei årrekke (1997-2013), hun har vært nestleder i Oslo-avdelingen av Foreningen Norden i to perioder og i regi av Human-Etisk Forbund har hun vært fast taler både på navnefester og ved begravelser. For Ruth er ingen oppgave for stor og ingen for liten, enten det dreier seg om å ha hovedansvaret for store internasjonale konferanser (bl.a. Euralex-konferanse på Blindern i 2012) eller å koke risengrynsgrøt til juleavslutningen på avdelingen. Og enten arrangementet er stort eller lite, så liker hun å ha regien. Og da kan vi andre ta det rolig, vi vet at den er i de beste hender.

Jeg husker Ruth også som en miljøbygger. Mens vi holdt til nede på Chateau Neuf, inviterte hun i flere år ikke bare oss på Avdeling for bokmål, men hele språkmiljøet som holdt til der, Norsk Ordbok, Avdeling for gammelnorsk og mellomnorsk og Institutt for navnegransking, på hagefester hjemme hos seg i Mylskerudveien, fester som jeg minnes med stor glede.

Ruth har gjennom mange år vært en god og inspirerende kollega, og jeg drister meg til å si også en god venn. Hun fortjener både et jubileumssymposium og en hyllest i bokform!

Boye Wangensteen

mangeårig kollega

KONTAKT

Boye Wangensteen

Pensjonert leksikograf, Institutt for lingvistiske og nordiske studier, Universitetet Oslo boye. wangensteen@hotmail.no 
